\title{
A Study of Solo-Livers in Eastern Asia: an Eye on Japan, China and South Korea
}

\author{
Olena Muradyan - \\ PhD in Sociology, Associate \\ Professor, Department of Political \\ Sociology, Dean of the School of \\ Sociology, V. N. Karazin Kharkiv \\ National University, Ukraine \\ E-mail: o.s.muradyan@karazin.ua \\ ORCID: https://orcid.org/0000- \\ 0003-0990-9635
}

\author{
Daria Yashkina - \\ PhD student in Sociology, School \\ of Sociology, V.N. Karazin Kharkiv \\ National University, Kharkiv, \\ Ukraine \\ E-mail: \\ yashkinadarya96@gmail.com \\ ORCID: https://orcid.org/0000- \\ 0003-4454-4555
}

DOI: $10.29038 / 2306-3971-2020-$ 02-76-84

Reseived: October, 2020

$1^{\text {st }}$ Revision: October, 2020

Accepted: November, 2020
The article examines how the processes of individualization (which in the modern world lead to many social changes, including lifestyle changes) alter the attitude to the need to start a family. Such processes also lead to the emergence of such phenomenon as "solo-living", but the analysis of the existing studies has shown that the growth of singles has not been researched in global comparative studies. The authors analyze how the problem of singles' growth in East Asian countries (with the focus on Japan, China and South Korea) is considered. Asian studies show that the lifestyle of single people is dictated by several reasons: lack of free time due to work (imbalance between work and life outside it), opposition of young people to official policies of their countries (social policy is aimed at supporting family traditions) and support for such lifestyle by marketing companies (the market is increasingly focused on singles in these countries). Prospects for further research include considering confrontation of social policies of the states and market policy on the issue of solo-living and the analysis of local studies of solo-living.

Мурадян Олена, Яшкіна Дар'я. Дослідження життя соло в Східній Азії: погляд на Японію, Китай та Південну Корею. Процеси індивідуалізації в сучасному світі призводять до багатьох соціальних змін, у тому числі й до змін стилів життя. Змінюється ставлення до необхідності створення сім'і, починають виникати такі феномени, як «solo-living», проте зростання одинаків не досліджується в рамках глобальних порівняльних досліджень. У межах статті проводиться аналіз того, яким чином розглянуто проблему зростання одинаків у країнах Східної Азії на прикладах Японії, Китаю та Південної Кореї. Автори роблять висновок, що азіатські дослідження демонструють тенденцію, що стиль життя одинаків продиктований нестатком вільного часу через трудову діяльність, протистоянням молоді офіційним політикам своїх держав та підтримкою такого стилю життя маркетинговими компаніями. Перспективами подальшого дослідження тематики є розгляд протистояння соціальних політик держав і політики ринку щодо питання solo-living.

Ключові слова: соціальні зміни, стиль життя, solo-living, публічний і приватний простір, Східна Азія.

Мурадян Елена, Яшкина Дарья. Исследование жизни соло в Восточной Азии: взгляд на Японию, Китай и Южную Корею. Процессы индивидуализации в современном мире приводят ко многим социальным изменениям, в том числе и к изменениям стилей жизни. Меняется отношение к необходимости создания семьи, начинают возникать такие феномены, как «solo-living», при этом рост одиночек не исследуется в рамках глобальных сравнительных исследований. В рамках статьи проводится анализ того, каким образом рассматривается проблема роста числа одиночек в странах Восточной Азии на примерах Японии, Китая и Южной Кореи. Авторы приходят к выводу: азиатские исследования показывают, что стиль жизни одиночек продиктован недостатком свободного времени из-за трудовой деятельности, противостоянием молодежи официальным политикам своих государств и поддержкой такого стиля жизни маркетинговыми компаниями. Перспективами дальнейшего 
исследования тематики является рассмотрение противостояния социальных политик государств и политики рынка по вопросу solo-living.

Ключевые слова: социальные изменения, стиль жизни, solo-living, публичное и приватное пространство, Восточная Азия.

Statement of a Scientific Issue and its Significance, Relevance of Research. In modern conditions, due to the development of individualization, economic, demographic and other modern changes to the extended and nuclear forms of the family, which are the most common forms of the family ${ }^{1}$, new less typical types of families begin to be added, and the phenomena of family abandonment as such begin to appear. For example, the share of single households in Europe, America and Asia is increasing: as of 2019, the share of singleperson households in Europe is 39 \% (Eurostat, 2020); as of 2020, 36,2 million US households consist of one person (this is $28 \%$ of all households) (Statista, 2020a). The total global growth of single households for the period from 2010 to 2019 was $31 \%$, half of which in absolute terms are households in the Asia-Pacific region (Rude, 2020).

Increasing the number of divorces, economic instability, lack of time due to employment and the growing popularity of hedonism (the motivational goal of which, according to Schwartz's theory of values, is pleasure, sensual pleasure, enjoyment of life; gendonism is based on the need to meet biological needs and feels this) all this encourages individuals to postpone the creation of a family or abandon it altogether, which becomes a manifestation of social change in almost all developed countries from Norway to Japan (Ortiz-Ospina, Roser, 2020). Z. Bauman in his book «Liquid Modernity» (Bauman, 2008) pointed out that the existing patterns of lifestyles become fluid and changeable, so the task of individuals is to build their own way of life. W. Beck and E. Beck-Gernstein in their theory of individualization pointed out that changes in the stability of relations, kinship between people and marriage as such lead to the prevalence in society not of the family as part of society, but of the individual (Beck, Beck-Gernsheim, 2012). Back in 2001, Baumann stated in his work «The Individualized Society» that individualization had come a long way (Bauman, 2005, p. 68): we see that these theories were developed almost two decades ago, and statistics on the growth of single and one-person households around the world indicate that processes of individualization - a trend that is deeply rooted in all social processes nowadays, despite the cultural traditions and other features of different societies around the world.

In the framework of our paper, we address the problem that the number of single individuals is growing around the world, but each region has its own specifics of how such growth is reflected in the social status of society, what the way of life of single people from around the world is and how this problem is being studied in different societies. Here, the concept of «way of life» refers not only to the way people organize their daily lives. It is also associated with the identification of those socio-cultural assessments that give representatives of different socio-cultural groups their own way of life, the way of life of others, as well as the current state of social and cultural life in general (Muradyan, 2012, p. 81).

The question arises: what is the difference between such manifestations of individualization in countries where traditions of preserving the family are more ingrained, and in those countries where the processes of «detraditionalization» ${ }^{2}$ began earlier, and how different the consequences of such processes may be?

Analysis of Recent Research on This Problem (Theoretical Foundations of the Study, Methodology and Characteristics of the Empirical Basis)

The problem of increasing the importance of single individuals in societies, as already noted, began to pay more attention at the beginning of the 21st century against the background of the development of concepts of individualization (W. Beck, E. Beck-Gernstein, Z. Bauman, E. Giddens). Studies of family decline were initially considered in the context of the sociology of the family, in terms of economics and consumption (through the prism of household research and marketing research), and so on. The American researcher E. Kleinenberg was one of the first researches who approached the most comprehensive approach to the issue

1 According to a Pew Research Center report for 2019, $38 \%$ of households worldwide are expanded types of family, and households consisting of two parents and a child are $22 \%$ of the total. (Religion and Living Pew Research Centre: Religino and Public Life (2019). Arrangements Around the World. Retrieved October 16, 2020 from https://www.pewforum.org/2019/12/12/religion-and-living-arrangements-around-the-world/)

${ }^{2}$ By definition of U. Beck 
of singles and single life in his work «Going Solo: The Extraordinary Rise and Surprising Appeal of Living Alone». He identifies several main reasons for the growing number of individuals who choose to live alone: individualization, Internet communications, capitalism, urbanization and globalization as it is (Klinenberg, 2012). All these reasons are typical mainly for economically developed countries, respectively, the number of solo-living is growing there. But since these processes take place differently in each region, this lifestyle will be different in regional aspect, expressed and studied differently.

It is worth noting that none of the global comparative studies has paid specific attention to this issue. Global research projects such as World Values Survey, European Values Survey, European Quality of Life Survey, European Social Survey, European Working Conditions Survey, Eurobarometer, Afrobarometer, Arab Barometer, Human Development Report, Life in Transition, etc., provide an opportunity to outline (and analyze) the group of «so called» solo-livers only if the filter is used based on the composition of the family/ household. However, this does not always make it possible to correlate these data with a real group, as the statement of declarative formal solitary residence may have nothing to do with solo-living as a life strategy.

Formulation of the Purpose and Tasks of the Article. The purpose of this article is to characterize the regional features of the social life of individuals as a manifestation of the processes of individualization. Accordingly, the objectives of the article are to analyze studies of single individuals in different regions of the world. The greatest attention will be focused on the United States and Europe and the countries of East Asia, as opposed to countries where the processes of individualization are more or less rooted in social life, and countries where the processes of individualization face «hard» traditionalism.

Presentation of the Main Material and Substantiation of the Obtained Research Results. Thus, the 21 st century puts the individual in a situation where his/her life path depends mainly on him-/herself, such a situation combined with the fluidity and uncertainty of the future provokes the emergence of very different and a kind of unconventional lifestyles, such as «solo-living» - living alone, postponing starting a family life and increasing the number of single people (Yashkina, 2020). It is worth noting that, certainly, a fairly large proportion of single households are households consisting of the elderly according to the World Health Organisation classification (60+), but the global trend is also an increase in the number of such individuals among young people (Bentley, McCallum, 2019). Singles in this study are those who deliberately do not start a family, regardless of their previous life experience (divorce, etc.). It is important that in each country this lifestyle is manifested differently and each region has its own specific phenomena are inherent in singles. Of particular interest in this context are the countries of East Asia, because despite the idea of them as countries where family traditions come first, the statistics of single people living separately from families are not inferior to other developed regions. Also note that the countries of East Asia, for example, according to the World Cultural Map of R. Inglehart - K. Welzel have a fairly high level of values of self-expression and secular values and are located on the scale of «traditionalism-secularism» at the level of most European countries (World Value Survey, 2020).

The general situation in Asia in the late 20th and early 21st centuries.

The end of the 20th century for East Asian countries was marked by the great financial crisis of 19971998. At the moment, we see that the economic downturn was only temporary, but it was the forerunner of the opening of Asian countries to the global market and active involvement in globalization. The crisis also exposed the shortcomings of social protection systems, the widening income gap and inequality across the region over the next 10 years after the crisis, as demonstrated by Ginny's dispersion ratio. China showed a larger gap than the United States, and Japan had greater inequality than the average industrialized country (Burton, Zanello, 2007). Such a gap, the development of technology and urbanization has led to very fierce competition in the employment market, the need for skilled workers has increased. At the same time, the number of single households grew.

Thus, as of 2019, the largest number of single households was recorded, namely: the countries with the largest number of single-person households - Japan, South Korea, Thailand, Taiwan and China (Rude, 2020). Within the framework of this work, three countries will be considered - Japan, China and South Korea, because, in our opinion, it is possible to determine the specifics of considering the lives of single people there.

Japan

According to the Family in a Changing World study (2010), the proportion of women who have never been married over the age of 40 was 16,1 \% in Japan (Families in a Changing World, 2019). And in 2015, 
almost one in four men and one in seven women in Japan remained unmarried before the age of 50 (South China morning post, 2017). Japan was one of the first countries to raise the issue of singles, but not in the typical context at the time. Here for the first time they spoke about the so-called «Parasite singles». In 1997, the Japanese researcher J. Masahiro published the book «The Age of Parasite Singles». According to the author, single parasites, or solitary parasites, is a term for young people who lead a fairly hedonistic and welloff lifestyle without starting a family. According to the 1995 National Census, up to $60 \%$ of men and up to $80 \%$ of women between the ages of 20 and 34 in Japan lived with their parents. In this regard, Masahiro foresaw the great influence of this group of single people on the economy, the state of society and the demographic in general. The theory of J. Masahiro was elaborated by the Japanese researcher Yu Genda; it should be noted that J. Masahiro was quite critical of such «parasites» and blamed them for the future problems of Japan. Genda elaborated Masahiro's concept by noting that it was not the choice of a hedonistic lifestyle that left young Japanese without work and financially dependent of their parents, but the lack of jobs. Unemployment (which at the time was higher than among US youth) prevented them from starting families and leaving their parents' homes (Sean, 2001). It is estimated that in 2016 there were 4,5 million unemployed people aged 35 to 54 who were not married and lived with their parents. This trend leads to the fact that in $2065,40 \%$ of the population will be elderly, a significant proportion of whom will live at the expense of the state after the death of their parents, at whose expense they lived before (English, 2017). Over time, this trend began to be observed in other countries (such as Britain), but the alleged problems with young people living with their parents in Japan were further developed and «parasites» moved to another, less critical phenomenon of «snepers» (SNEP - Solitary Non-Employed Person) and the age range was from 20 to 60 years.

«Snepers» never married and do not plan to, do not work anywhere, live at the expense of their parents/ brothers/sisters or at the expense of social support of the state. With the introduction of this phenomenon in the social reality of Japan, began its development and a new term - «freeters» - who are those young people who after graduating from universities or schools have never worked anywhere. As this group is deprived of any activity, except leisure, most often the social support networks of such individuals are quite small, which in turn can cause feelings of loneliness and isolation among «snepers». Japan's social policy is aimed at combating this along with overcoming unemployment. But it is worth noting that despite the state's efforts to preserve the «sociality» of «snepers», the phenomenon of «hikikamori» began to spread in Japan. «Hikikamori» are those who have not left their homes at all for months, a phenomenon caused by the development of Internet technology, due to which, on the one hand, one is able to get everything one needs to live without leaving home, on the other - online network games completely «transfer» individuals into the virtual world. However, an increasing number of researchers characterize this phenomenon as a kind of modern mental disorders (Teo $\&$ Gaw, 2010). It is worth noting that the share of «snepers» who still find a job, often no longer actually have a chance to start a family, because work takes up all the time, and the ethics of communication at work does not always give a chance to even find friends (Kato, Kanba, \& Teo, 2019; Genda, 2019; Genda, 2014). The consequence of such a prevalence of social isolation is the development of such commercial services as, for example, «cafe hugs». This is a service where for money a man or a woman can spend a night or a few hours lying in the arms of a «specially trained person», but such hugs are not intimate (Jyotis, 2020) (it should be noted that such «cafes» have become popular in the USA (Bogdanchikova, 2017), which can be interpreted as a kind of commercialization of feelings, which in his works writes Israeli researcher Eva Illouz (2019)). In search of a way out of the situation of increasing socially isolated unemployed, the authorities of the city of Fujisato in Akito prefecture, where the aging rate was the highest, together with social workers organized jobs for snipers: snipers producing bread products with local maitake mushrooms and more (Genda, 2014). However, in addition to snappers, who are considered an almost socially isolated category of the population, there is also the concept of «chitorigurashi» - those who consciously choose to live solo. This category of people, certainly, works and has the means for a self-sufficient social life, but after work they choose to be alone. They used to eat, drink and spend their leisure time alone, the Japanese market quickly picked up on this trend, and the world saw karaoke establishments for one person. For example, Koshidaka Kan noticed that $30 \%$ of visitors to their establishments sing alone, and organized single booths for solo singers (Rethink Tokyo, 2019). That is, on the one hand, we see Japan trying to overcome the growing social isolation and unemployment of young people, but on the other hand, the number of young people for whom this lifestyle is normal is growing. 


\section{China}

As for China, the number of one-person households was $14,6 \%$ in 2013 , which is 2,4 times more than in 1990 (6 \%). From 2015 to 2020, the number of single-person households increased from 58 million to approximately 77 million (Content Commerce Insider, 2020). Such statistics is explained in China mainly in two ways: as a consequence of the global trend of later marriage and as a consequence of the one-child policy (which were functional for 40 years (1976-2016)), which reduced the family size in China and allowed to «get used» to fewer relatives around (Yaoti, 2016). The one-child policy has resulted in 32 million more men than women in China (according to Chinese tradition, a boy should take care of his parents in old age, so the birth of a boy was more important than the birth of a girl, so this led to wave of abortions and murders of baby girls (Winter, n.d.), which significantly reduces men's chances of marriage now.

In general, during the years of economic boom in China, not only a whole generation of single children has grown up due to gender imbalance (disparity between males and females in a population), but the country's population is gradually aging. China's population is projected to reach 1,4 billion by 2040 , with a quarter of the population over the age of 65 , and then population growth will virtually stop, posing a direct threat to economic stability. A limited reform of the one-child policy took place in 2013, when a married couple was allowed to have two children (if both - husband and wife - were single child in their families). Relatively few families have used this permit due to low income. According to experts, the transition to the policy of two children was too late and it is not enough to solve China's demographic problems nowadays.

As for today, on the other hand, Chinese traditions and culture believe that a girl should get married before the age of 25, so unmarried girls are often treated with contempt. In 2007, such a group of women received the official name «sheng-nu» (Richardson, 2015), which translates as «remaining women». At the time when unmarried men are called «guang-gan» - «bare branches», because they do not add branches to the «family tree». But also the common name of such men is «golden bachelors». It is also important that marriage is very significant for the older generation of Chinese, so even today in Shanghai there is a «bride market»: a market where parents come with photos of their unmarried children and conditionally «sell» them to other parents. A characteristic feature of today's market is that mostly men are for «sale», and due to the complexity of selection and the rich number of requirements of candidates, parents often turn to professional matchmakers for help. It is worth noting that often such relationship markets are created at the initiative of parents only, and children simply out of respect for their parents do not deny their sale (Schmitz, 2018).

In general, both women and men admit that they do not have enough time to start a family because of work. But despite traditional ideas, they do not see this as a big problem as their parents and the state. This position of young people is also supported by the media, so in recent years in China the popularity of live broadcasts and reality shows about the lives of people living alone. China's streaming platforms strive to keep up with current media market trends, so in the last few years, three Chinese platforms have released their shows, the main idea of which is to watch people living alone. Yes, «I want to live like this» from the iQiyi platform is gaining viewers due to the large number of media stars. The show «Not Aloner» focuses on the differences of generations (X, Z, millennials), and the program «Make life beautiful» is aimed at young people and adolescents. All programs were quite successful among their target audience. All three programs are now sponsored by the Chinese alcohol brand «Rio», and such sponsorship is part of a larger marketing strategy aimed at helping modern young Chinese spend time alone and not be stigmatized (Content Commerce Insider, 2020). China's services and entertainment also follows the trends of modern lifestyles, so, in China, such phenomena as karaoke booths for one, which is taken from the example of Japan, are quite popular. A unique feature of the Chinese market is the emergence of Single's Day (so called Singles Holidays) - a holiday of singles, which arose as a contrast to the St. Valentine's Day, and became the largest day of discounts in China and then around the world. Traditionally, the Single's Day shopping holiday is held on November 11, so on 11/11 - the unit symbolizes the individual (Kislev, 2019, p. 13). This year, sales for the Singles Holidays have reached enormous proportions. For example, JD.com said that in the first 9 minutes of the sale, orders for 200 million yuan (equivalent to about \$ 30,7 million) were received, and during the discount period, Chinese sales giant Alibaba earned $\$ 56$ billion and received a record number of orders: 583 thousand orders per second (Moneycontrol, 2020).

So we see that despite the older generation's efforts to maintain family priorities and accommodate their children, despite the older generation's misunderstanding of current trends and the traditionally high respect 
and esteem of parents, modern Chinese people are increasingly choosing to live alone and live independently. China's social policy has only just begun to feel and see the effects of one-child policy, while the market and marketing companies are increasing their profits by catching up with current trends and the needs of single people.

\section{South Korea}

As for the situation in South Korea, one-person households accounted for only $9 \%$ of the total number of households in 1990, and in 2013 the share of such households was already $26 \%$. According to the Statistical Office of Korea in 2035, this figure could rise to $35 \%$ (Park, 2015). This is due on the one hand to demographic trends: in 2018, 98 children were born per 100 women - which was the lowest figure since the beginning of statistics, and this figure continues to decline. On the other hand, same as in other Asian countries, the aging population is growing: about $15 \%$ of Korea's population is over 65 years old (Hektor, 2020). Significant in the context of this issue is the tendency to divorce. Until recently, the Confucian tradition of respect for the family in the Asian countries singled out in South Korea had the strongest impact on young people's lives: the question of individual independence and distance from the cult of the family gradually began to rise legally only in 1945 under the pressure of intensification of industrialization. Family and commercial law were revised few more times, and in 1958 the Korean Civil Code weakened the power of the head of the family and granted rights to the spouses (Sorenson, n.d.). But over time, this has also become a problem for Korean society, as the issue of the family's opposition to work and the role of a woman who has to work (under economic conditions) and be a housewife (according to tradition) has become more acute.

A 2006 study shows that $46 \%$ of married Korean women between the ages of 25 and 54 were full-time housewives, and those Korean married women who worked also did $80 \%$ of the housework, while their husbands did only $20 \%$. Over time, women began to refuse marriage precisely because marriage forced them to do housework, unlike men. Another important reason for Koreans to refuse marriages and dating in general is the instability of the economic situation and lack of time (because in South Korea there is a long working day, in 2017 Koreans worked 500 hours more per year than the French, and 300 hours more than Canadians) (Qian, 2019).

On the other hand, in 2019, the unemployment rate in Korea reached the highest level in 17 years $-3,8 \%$, and the youth unemployment rate $-10 \%$. After graduating from university, only every 10th student found a full-time job (ie full-time employment). Due to high competition in the labor market, most young people spend their free time not on dates, but on additional courses, receiving additional certificates to confirm their professional ability (Jeong, 2019).

Under such conditions, the Korean government is trying to implement mechanisms that will increase the birth rate in Korea on the one hand, and will increase the number of families, or at least young people who go on a date - on the other. For example, in 2010 the government tried to implement a policy of turning off electricity in ministry buildings once a month after $7 \mathrm{p} . \mathrm{m}$. so that workers could go home to make love and, as a result, have children (Liang, 2016).

Attempts to increase marriages have also been introduced in university courses, for example, the course «Gender and Culture» at the University of Seoul is not required, but its specificity is that the practical objectives of this course are to meet with classmates. The university says that such courses are popular because a large number of students in their years have never been on a real date. The course also introduces various aspects of love, dating and sex. According to the Korean Institute of Health and Social Affairs, in 2018 most people between the ages of 20 and 44 were single, with only $26 \%$ of men and $32 \%$ of women in a relationship. And among those who were not in a relationship, $51 \%$ of men and $64 \%$ of women said they preferred to be single. There are two main reasons why young Koreans refuse to even date: it is very expensive and dangerous. A Korean matchmaking company has calculated the average cost of a date at $\$ 55$, which means that people with a minimum wage in Korea have to work 7,5 hours to pay a date expenses. And the Embrain survey showed that $81 \%$ of respondents consider the cost of a date as a source of stress in a relationship (Jeong, 2019). On the issue of danger, for example, from 2011 to 2017, the number of illegal snapshots of women increased approximately fivefold (women were filmed in their homes, photographed under skirts on the streets, spy cameras were installed in toilets, etc.), and recordings were often made by acquaintances or romantic partners of women - according to the Ministry of Gender Equality and Family (Jeong, 2019). An important problem is that due to the low «popularity» of dating and the difficulty of building relationships in 
such conditions, basic sexual experience and knowledge and intimacy young Koreans acquire through pornography, which leads to a distorted view of romantic relationships as such.

Thus in Korea the concept of «Sampo generation» was formed - a generation of three refusals - from dates, from marriage, from children (Brodie-Hall, 2018). It has become a way of life with established value priorities, among which career and financial stability come first. At the same time there is a lifestyle of young people - honjok. Hongjoks are individualized singles in a nation that is not individualistic in nature. That is, such a lifestyle is to some extent a confrontation with the traditions and policies of the government as such (DePaulo, 2020). Despite the efforts of the authorities, individuals in Korea will receive support from the media, the entertainment industry and the market; for example, Korea has one-person household banking services; very developed solo-economy (in the terminology of E. Klinenberg (2012): sets of dishes for one person, small washing machines, sets of products designed for one person, etc.). In restaurants and bars there are special tables for one, in cinemas there are separate places to watch movies alone; as in China, the shows about the lives of singles, for example, «I drink alone» are developed (DePaulo, 2020). Thus, we see that the characteristic of singles in South Korea is that they put their lifestyle at odds with traditional ideas and family. For them, family went from the first place (according to Confucianism) to the fourth place after financial stability, health and work (Statista, 2020b).

Conclusions and Prospects for Further Research. As a result, we have the following situation in these Asian countries: as in Europe, the number of singles is growing and solo-living lifestyle is actively developing everywhere, but with its own characteristics:

- the economic situation encourages young people to work, which does not involve the availability of leisure, i.e. in fact the work-life balance is made in such a way that there is simply not enough time to live outside of work;

- social policy directs all its efforts to reverse the dynamics of the spread of singles in the opposite direction, but this is partly what motivates young people to abandon starting a family;

- at the same time, the market, media and entertainment industry support the growing trend of solo-living in its various manifestations, as it sees that profits from this segment of consumers are growing; today, the Asian market is the main market for single goods.

Certainly, this list is not exhaustive and is layered on the list of other countries, but it is interesting and promising for further research in the region. We see the problem of confrontation between government policies to preserve family traditions and market policies that dictate their own conditions, which put an individual to the first place. The analysis of local studies of solo-living and its manifestations in Europe and the post-Soviet space will make a special area of research.

\section{References}

1. Bauman, Z. (2005). Individualized society. Moscow: Logos.

2. Bauman, Z. (2008). Liquid Modernity. Moscow: Piter.

3. Beck, U., Beck-Gernsheim, E. (2012). Individualization. Los Angeles: Sage.

4. Bentley, D., McCallum, A. (2019). Rise and Fall: The Shift in Household Growth Rates since the 1990s. Civitas. Retrieved October 15, 2020 from http://www.civitas.org.uk/content/files/riseandfalltheshiftinhouseholdgrow thratessincethe1990s.pdf

5. Bogdanchikova, M. (2017). I Will Hug You for Money: How They Made a Business Out of Tenderness. Marie Clarie. Retrieved October 15, 2020 from https://www.marieclaire.ru/psychology/obnimu-za-dengi-kak-iznejnosti-sdelali-biznes/

6. Brodie-Hall, G. (2018). The Sampo Generation: Why We Are Seeing the Lowest Fertility Rate of All Time? Retrieved October 8, 2020 from https://theobserver-qiaa.org/the-sampo-generation-why-we-are-seeing-thelowest-fertility-rate-of-all-time

7. Burton, Z., Zanello, A. (2007). Asia 10 Years Later. Finance and Development. Retrieved October 22, 2020 from https://www.imf.org/external/pubs/ft/fandd/rus/2007/06/pdf/burton.pdf

8. Content Commerce Insider (2020). Single Living and the «Homebody Lifestyle» Take Over China. Retrieved October 8, 2020 from https://contentcommerceinsider.com/blog/single-living-and-the-homebody-lifestyle-takeover-china

9. DePaulo, B. (2020). How South Korea Is Accommodating, Not Shaming, Singles Who Live Alone. Retrieved October 22, 2020 from https://www.unmarried.org/featured/how-south-korea-is-accommodating-not-shamingsingles-who-live-alone/ 
10. English, Ch. (2017). Japan: More Than Four Million Middle-Aged 'Parasite Singles' Still Live with Their Elderly Parents. Retrieved October 15, 2020 from https:/www.independent.co.uk/news/world/asia/japan-parasitesingles-four-million-middle-age-parents-live-childbirth-rate-unmarried-unemployed-a7692256.html

11. Eurostat (2020). Number of Private Households by Household Composition, Number of Children and Age of Youngest Child. Retrieved October 15, 2020 from https://ec.europa.eu/eurostat/databrowser/view/LFST_ HHNHTYCH_custom_206740/default/table?lang=en

12. Families in a Changing World (2019). Progress of the world's women in 2019-2020. OUN: Women. https://doi.org/10.18356/86036fb7-en. Retrieved October 8, 2020 from https://www.unwomen.org/-/media/head quarters/attachments/sections/library/publications/2019/progress-of-the-worlds-women-2019-2020-ru.pdf?la= en\&vs $=2801$

13. Genda, Y. (2014). SNEP Phenomenon: in Japan, the Number of Single Unemployed is Increasing. Retrieved October 22, 2020 from https://www.nippon.com/ru/currents/d00109/

14. Genda, Y. (2019). Solitary Non-Employed Persons. New York: Springer. https://doi.org/10.1007/978-981-137787-7

15. Hektor, A. (2020). The Korean Sampo-generation: the Lowest Birth Rate in the World. Retrieved October 27, 2020 from https://sweden-science-innovation.blog/seoul/the-korean-sampo-generation-the-lowest-birth-rate-inthe-world/

16. Illouz, E. (2019). Why Love Hurts. Cambridge, U.K.: Polity Press.

17. Jeong, S. (2019). For many young South Koreans, dating is too expensive, or too dangerous. Retrieved October 16, 2020 from https://edition.cnn.com/2019/05/11/asia/south-korea-dating-intl/index.html

18. Jyotis (2020). Cuddle Café in Japan: Customers Are Willing To Spend Over Rs 30,000 On A Sleep With Cute Girls. Retrieved October 22, 2020 from https:/gurugamer.com/viral/cuddle-cafe-japan-customers-rs-30-000sleeping-cute-girls-10514

19. Kato, T., Kanba, S., Teo, A. (2019). Hikikomori: Multidimensional Understanding, Assessment and Future International Perspectives. Psychiatry And Clinical Neurosciences. https://doi.org/10.1111/pcn.12895

20. Kislev, E. (2019). Happy Singlehood: the Rising Acceptance and Celebration of Solo-Living. Oakland, California: University of California Press. https://doi.org/10.2307/j.ctvd1c7r2

21. Klinenberg, E. (2012). Going Solo: The Extraordinary Rise and Surprising Appeal of Living Alone. Penguin Books.

22. Liang, Chong Zi (2016). S. Korean Civil Servants Turn Off Lights to Get Turned on. Retrieved October 27, 2020 from https://www.straitstimes.com/politics/s-korean-civil-servants-turn-off-lights-to-get-turned-on

23. Moneycontrol (2020). Alibaba Singles Day Sales Hit \$56 Billion with Record Peak of 583,000 Orders per Second. Retrieved October 16, 2020 from https://www.moneycontrol.com/news/business/alibaba-singles-daysales-hit-record-56-billion-at-583000-orders-per-second-6101481.html

24. Muradyan, O. S. (2012). Way of Life as a System of Social Action: an Attempt at Conceptualization. Sociological Studios, 1(1), 81-87.

25. Ortiz-Ospina, E., Roser, M. (2020). Marriages and Divorces. Retrieved October 16, 2020 from https://ourworldindata.org/marriages-and-divorces

26. Park, S. (2015). A Silent Revolution in the Korean Family. Contexts, 14(2), 77-79. https://doi.org/10.1177/ 1536504215585785

27. Qian, Y. (2019). Why Young People in South Korea are Staying Single Despite Efforts to Spark Dating. Retrieved October 27, 2020 from https://theconversation.com/why-young-people-in-south-korea-are-stayingsingle-despite-efforts-to-spark-dating-111486

28. Rethink Tokyo (2019). Going solo: The Japanese Preference for Living Alone. Retrieved October 27, 2020 from https://www.rethinktokyo.com/Hitorigurashi-living-alone-japan

29. Richardson, Wh. (2015). In China, Single Women Live by Their Own Rules. Retrieved October 16, 2020 from https://lens.blogs.nytimes.com/2015/08/14/in-china-the-single-ladies-push-back/

30. Rude, J. (2020). Half the World's New Single Person Households to Emerge in Asia Pacific. Retrieved October 8, 2020 from https://blog.euromonitor.com/half-the-worlds-new-single-person-households-to-emerge-in-asiapacific/\#: :text=Over\%202019\%2D2040\%2C\%20half\%20of,a\%20number\%20hard\%20to\%20ignore

31. Schmitz, R. (2018). China's Marriage Rate Plummets As Women Choose To Stay Single Longer. Retrieved October 22, 2020 from https://www.npr.org/2018/07/31/634048279/chinas-marriage-rate-plummets-as-womenchoose-to-stay-single-longer

32. Sean, J. (2001). Parasite Singles: International Perspective and Analysis. Retrieved October 16, 2020 from https://academic.csuohio.edu/makelaa/history/courses/his373/ParasiteSingles.htm

33. Sorenson, S. W. (n.d.). The Value and Meaning of the Korean Family. Center of Global Education. Retrieved October 16, 2020 from https://asiasociety.org/education/value-and-meaning-korean-family 
34. South China Morning Post (2017). One in Four Japanese Men aren't Getting Married until Age 50 - and That's Not Good for the Country's Low Birthrate. Retrieved October 16, 2020 from https://www.scmp.com/news/asia/ east-asia/article/2085016/one-four-japanese-men-arent-getting-married-until-age-50-and

35. Statista (2020a). Number of Single-Person Households in the United States from 1960 to 2020. Retrieved October 16, 2020 from https://www.statista.com/statistics/242022/number-of-single-person-households-in-theus/\#: :text=This\%20statistic\%20shows\%20the\%20number,households\%20in\%20the\%20United\%20States

36. Statista (2020b). Love and Sex in South Korea. Retrieved October 16, 2020 from https://www.statista.com/ topics/6708/love-and-sex-in-south-korea/

37. Teo, A., Gaw, A. (2010). Hikikomori, a Japanese Culture-Bound Syndrome of Social Withdrawal? The Journal Of Nervous And Mental Disease, 198(6), 444-449. https://doi.org/10.1097/NMD.0b013e3181e086b1

38. Winter, W. (n.d.). China's Infanticide Epidemic. Human Rights and Human Welfare, 9, 1-9. Retrieved October 22, 2020 from https://www.du.edu/korbel/hrhw/researchdigest/china/InfanticideChina.pdf

39. World Values Survey. Retrieved October 22, 2020 from http://www.worldvaluessurvey.org/photos/cultural_ map_2020.jpg

40. Yaoti, R. (2016). As Traditional Family Lifestyle Breaks Down, More Youngsters are Living Solo Than Ever Before. Retrieved October 16, 2020 from https://www.globaltimes.cn/content/1004195.shtml

41. Yashkina, D. (2020). Heuristic potential of emotional labor concepts, trust and public space in the study of sololiving. Ukrainian Society, 1, 41-51. https://doi.org/10.15407/socium2020.01.041 